\title{
IN MEMORY OF MARK JONES
}

Mark Jones was the Manager of the BBC Sound Archives in the 1980s when I became Manager Audio and Cameras at the BBC Open University Centre in Milton Keynes - a new city about $60 \mathrm{Km} / 40$ miles north of London. The BBC Open University operation had only just moved from Alexandra Palace - site of the original BBC television studios opened in 1936 - when I joined the centre in 1982. I swiftly discovered that, in addition to running the radio and TV studio and location crews, I was also responsible for the sound tape and disc libraries.

Being in charge of a new store area which required fitting out with shelving and also being new to the problems of storage of $\mathrm{AV}$ materials, I sought advice from within the BBC. Mark was the first person that I contacted and he proved to be a ready source of advice and support to me while I was learning about AV library and archive operations. He also introduced me to Helen Harrison, the then Secretary-General of IASA, who was sitting in the Open University Library - about 100 metres away from my desk. Helen arranged for Dietrich Schüller to visit the University and as a result, Mark, Helen and Dietrich "persuaded" me to join IASA.

My involvement with Mark increased when he negotiated the use of a spare editing room at Milton Keynes to copy BBC programmes for placing in the BBC sound archive. The system that the Sound Archive under Mark used was to copy the transmitted tape, with all the tape splices, on to two new, uncut tapes. One copy was monitored while being recorded and this was placed in the archive proper. The other copy was only spot-checked and was the access copy. The idea was that, if a fault was found on the unmonitored access copy, the archive copy was known to be OK.

Mark was a keen supporter of the work of IASA and was the Treasurer from 1993 to 1999. He was elected Treasurer in 1993 with much to clear up after the previous Treasurer had resigned unexpectedly before the end of her term of office. This was a period of some turbulence in the finances of IASA, but Mark brought the association through the turmoil with his characteristic calm and good humour. He left the association in good financial shape when he handed over the job of Treasurer to Pekka Gronow in 1999.

While Mark was an active supporter of IASA and presented a number of papers to the Annual Conference, he was rather notorious for not spending much time sitting through papers that were not of interest to him. He preferred to visit museums and galleries in the conference town. At one Farewell Dinner, he was given a card signed by many of his friends with the message "Wish that you could have been here." He took the joke in good part.

\section{George Boston}

